\title{
Art in the Informational Mode
}

\author{
Dr. Glenda Nalder \\ Griffith University, Brisbane, Australia \\ g.nalder@griffith.edu.au
}

\begin{abstract}
This paper provides a brief overview of significant developments in new media arts practice and theory during the period 1996-2001. It draws from a web-based hypermedia doctoral dissertation entitled 'Realising the virtual: the internet as a space for transformatory art practice' which incorporates creative works undertaken as research and praxis. The dissertation addressed the question of the potential of internet-based new media arts practice, as a form of cultural activism, to effect positive social change. The paper traces shifts in art's orientation, through computer and telecommunications mediation, from that of 'a work' to that of 'median (from materiality to temporality); and in its operational mode, from that of the tele-visual to the tele-matic (from vision at a distance to data-banking at a distance). A key focus is the evolution of a new genre, 'netArt', the basis for which is critical engagement 'in the mode of information'.[1]
\end{abstract}

Key words: netArt, new media arts, internet art, living systems, cyberculture

\section{Introduction.}

The aim of my doctoral study was to gauge the potential of internet-based new media arts practice, as a form of cultural activism, to effect positive social change. My starting point was the assumption that new information and communications technologies and systems (NICTS) could facilitate a critical (deconstructive) art practice. This assumption was based on the view that, once captured in digital format, existing still and moving images, text and sound could be more easily manipulated and re-presented in such a way as to problematise or alter meaning (a strategy known in the field as 're-mediation'). The study was shaped by such influences as the speed of technological change, the limitations on access to NICTS and tech-know-how, the complexity of the global context, and the diversity of disciplines contributing to the debates surrounding NICTS. Assessment of the transformatory potential of internet-based art practice was found to be contingent upon an understanding of the specificities of the informational mode, as well as complex models of culture and society, and the place and 'work' of art within them

At the outset of the study, access to hardware, software and know-how was highly inequitable across sex, class, race ethnicity and cultural divides. With the growth of private internet service provision during subsequent years, these issues tended to be subsumed under the neoliberalist banner of internet democracy. While the subsequent creation of the world-wide-web and graphical web browsers encouraged some artists to exhibit reproductions of artworks created in traditional (or 'old') media in a new context that would liberate them from the gallery system, others using computers to generate (rather than merely digitise) art, in an off-line context, expanded their repertoires of practice to incorporate the informational mode. At first this meant either collaborating with computer programmers, or mastering new (computer) languages and information systems. But ultimately it was to mean a whole new way of thinking about the world and the place of art within it.

This new way of thinking evolved through a process whereby my object of study - the internet - was treated as a series of parallel, evolving 'worlds', 'spheres', or 'spaces' - each with its attendant problems, promises and politics simultaneously constructed through interactions between artists and between artists and other aggregations. It resulted from a deeper and broader inquiry into the network of relations of power underpinning technics (the human use of technology in the world) - or, to use Harraway's catch-all phrase: 'the kinship of the chip, gene, seed, bomb, lineage, ecosystem, and database.'[2]

\section{Art and technics.}

Intellectuals examining the impact of technics on the practice, mediation and reception of art have typically begun with Walter Benjamin's analysis, between the two World Wars, of the aesthetic, social and political implications of art in the age of technological 
reproducibility. [3] A sustainable feature of this work is its emphasis on the means by which the artwork 'takes place' and 'takes its place'. A single viewer of a painting hanging on the wall of a gallery stood before the work and experienced its aura - its olfactory and other qualities of originality - in a revered setting. Once mediated by technology, this aura was lost. For example, as cinema, art became actualised at the moment of its reproduction by a mass audience, thereby providing a significantly different experience. Artists quickly grasped the revolutionary potential of the photographic technique of montage as a distinctive experimental film editing technique, and the power of the dissolve to collapse space and time. In his critical readings of such filmic spectacles as the rallies of the Third Reich, and the 1936 Berlin Olympics, Benjamin asserted that the masses, seeing themselves face-to-face in the cinema, were able to be organised and mobilised 'at a distance'.

Benjamin's foundational work provided a language and a lens through which late $20^{\text {th }}$ century theorists of art and media were able to begin to describe the aesthetic, cultural and social transformations taking place with the proliferation of NICTS. Weber [4], for example, proposed that art's auratic qualities did not disappear, but were reproduced as 'mediaura' in and by the very media responsible for its decline. And, like Virilio, [5] he argued that machine or artificial vision in the form of the digital scan (or the virtual gaze) constituted sight without the look. Poster [6] urged us to consider the liberatory potential of the informational mode, which he believed reversed the old (one-to-many) order of communication, un-massing the audience, making senders receivers, producers consumers, and rulers ruled. While media and cultural theorists placed NICTS and the activities they supported under scrutiny using processes drawn from post-structuralist and post-modern critical theories, artists searched for new metaphors and new mythologies through which our place in this politically-invested, layered web of scientific, social, commercial, and cultural worlds might be understood.

\section{From realism to algorithm.}

Laurel [7] observed in the early 1990s that artists working at the cutting edge of digital media had moved on from constructing images that deployed realism as style, to using computers and new knowledge bases to create intricate models of objects. That artists sought new knowledge about natural phenomena from the domain of the physical and biological sciences, for example, seemed ironic when they were working in a nonnatural (synthetic, silicon-based) format. However this interest arose in the context of high-end parallel computing, which not only fast-tracked the study of natural processes but produced unexpected and exciting insights that fuelled computing scientists' belief in their capacity to create artificial intelligence and artificial life by mimicking natural processes. Artists, too, were seduced by the idea that a 'second' nature could be created through the generation of gene pools from which they might grow worlds of endless variety. Using computer algorithms to generate complex forms that took on the appearance of exotic plant life growing and evolving in a virtual garden was more exciting and challenging than merely manipulating scanned images. Thus by the early 1990s artists working in this 'second nature' genre introduced audiences to notions of living systems, and feedback as a mechanism for evolutionary change. Responding to this new work, which treated audiences not as external observers, but participants whose behaviour was integral to the evolution of the work, shifted art discourses onto the territory of physicists, and the corporate psychologists and socio-biologists, whose attempts to model behaviour were based on Weiner's 'science' of cybernetics and Darwinian evolutionary theories.

\section{From the televisual to the telematic.}

By 1996, cooperative and altruistic exchanges between computing scientists, systems engineers and information technologists resulted in crucial new developments such as the WWW, a graphical information browser (Mosaic), and new conventions for dynamic 3-D virtual reality modelling language (VRML) which gave artists a system able to support a convincing representation of spatiality. 


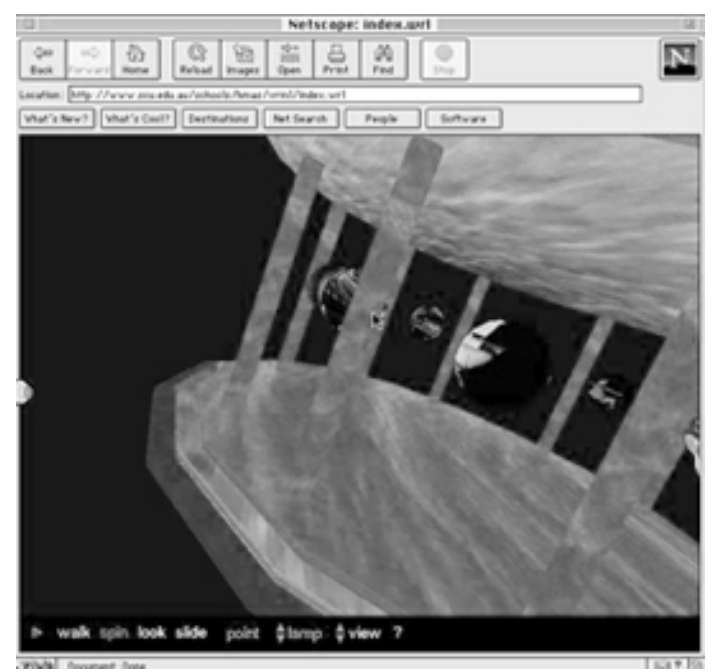

3D 'fly through' Navigation screen from the website "Asteria" (1996), scripted in Virtual Reality Modelling Language (VRML) in Nalder, G. (2001) Realising the Virtual: the internet as a space for transformatory art practice. [8]

These and other new tools developed in the same cooperative spirit and distributed via the internet as 'free-ware' and 'share-ware' for graphics, animation and sound editing and compression enabled artists to experiment and create low-cost virtual environments - not merely as repositories or exhibiting spaces for art that challenged the art institution, but as art.

Once '@ home' in cyberspace, we joined web communities, exchanged information, and engaged with the discourses of cyberculture. Adopting the informational mode of praxis enabled personal and local issues to be brought to global attention, and support to be rallied for local issues of global concern. However it was equally apparent that the informational mode facilitated tele-matics - the linking together of formerly discrete data-bases into data-banks - that, in the minds of many, constituted the 'superpanoptican' of the late twentieth century, Not only were our habits of consumption recorded, but also our physical location, health, employment and legal statuses. Rather than merely presenting us with visions from afar (tele-vision), NICTS constructed us as subjects in particular ways. Impoverished database languages reduced or omitted qualifying information so as to achieve the required nonambiguous grammatical structure, and used norms to constitute individuals and define deviants. Databases were not merely '... an invasion of privacy ... a threat to a centered individual, but ... the multiplication of the individual, the constitution of an additional self, one that may be acted upon to the detriment of the 'real' self without that "real" self ever being aware of what is happening.' [9] Whilst positing the existence of some 'real' or essential self is highly problematic, Poster's assertions did give expression to a collective anxiety about the intrusion of NICTS into our daily lives, and loss of a unified sense of self.

Kroker and others described the phenomenon as 'an ideology of panic ... linked to the rise of a new right' and based in 'the nihilism of a middleclass gone authoritarian', fuelled by '(f)ear of loss of privilege, impotence in the face of overwhelming power and despair over the failure of the liberal consensus to produce a psychological readiness for the therapeutic of the authoritarian state'.[10] However rather than accept our 'terminal condition', Goodall proposed that we re-think our response to excessive aesthesia (the epidemic of stress) through recourse to the work on aesthetics as a practice of the self, to question 'whether hypochondria, ... disguised as moral responsibililty' might be 'insulating us against the intellectual effort of interrogating the notion of adaptation itself.' [11]

\section{netArt.}

Visual artists/programmers, Starrs and Cmielewski's tongue-in-cheek Diagnostic Tools for the New Millennium enabled users to gauge their level of paranoia by completing web-form questionnaires. During the task the browser information bar began displaying information apparently gleaned from the user's computer by 'intelligent' client tools. Users not only became confused about whether their personal information was being hacked by the artists or by some smart programming within the browser itself, but became even more anxious about how far that personal information would travel and to what sinister uses it might be put.

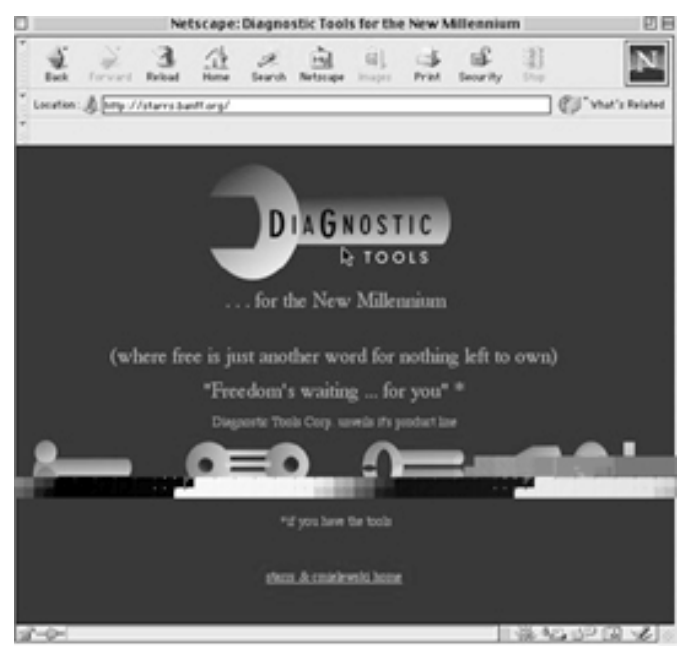


Screen from Diagnostic Tools for the New Millennium by artists Starrs and Cmielewski (1997) an interactive web-site playing on the growing paranoia of users by displaying their personal details in its information bars.[12].

Although semiotic and psycho-analyses of computer culture focused our attention on the irrationalities of a so-called rational and rationalising science and tools and pushed critiques of technics beyond simplistic good/evil polarisations, research into consciousness such as that by neuro-biologist, Maturana [13] brought new understandings and insights into the relationship between languaging and self-creation. Maturana's explanations also reinforced what psychoanalysis and art have always maintained: that it is only through access to the so-called irrational (or unconscious) forms of languaging that an understanding of the nature of consciousness (or 'soul') can be reached. This perspective reversed the 'top down', logicalrationalist approach originally favoured in artificial intelligence (AI) and artificial life (AL) research. On the basis of these new understandings, tele-matic culture could be conceptualised in terms of a self-organising, living system, made up of humans and artefacts in relation. Thus transformatory potential could be seen to reside in the ability to adopt the stance of an 'information-processing entity, able to change nature according to the information flows it receives and the various media to which it connects'.[14]

A living systems model that did not place responsibility for adaptation to changed conditions solely on any entity appeared an effective way of personalising complexity. In this model, netArtists create patterns of thought by dispersing ideas in the feedback loop of the narrowcast (many-tomany) informational mode. A networked model of communication is not subjected to the same kinds of controls and delays as hierarchical models.

Within the relatively short space of the five years from the mid to the end of the 1990s, netArtists had initiated, historicised, and noted the demise of their genre. The dominant feature of netArt in its 'high' or 'heroic' period was the artists' treatment of NICTS not merely as the tool of communication, but as the subject of their art.

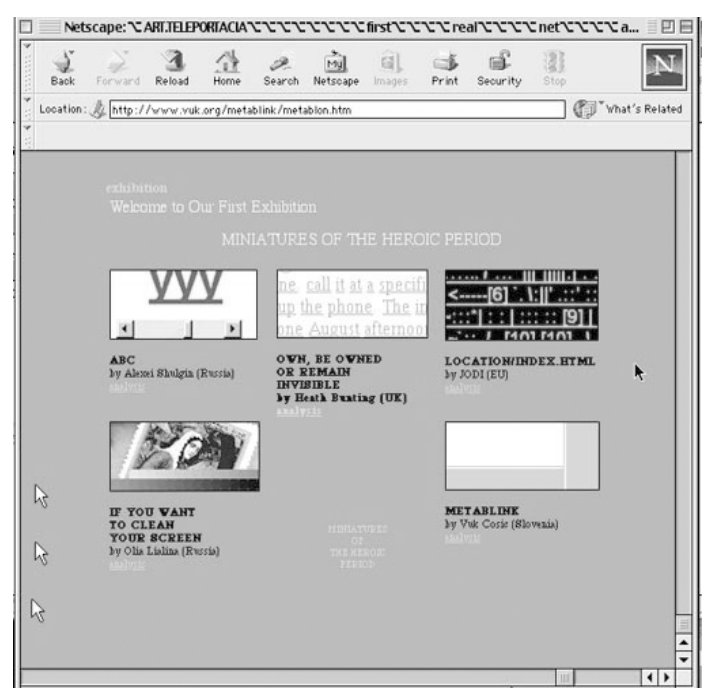

Screen from ArtTeleportacia Exhibition Miniatures of the Heroic Period featuring the work of Lialinas, Bunting, Shulgin, Jodi, and Cosic, each altering their site visitor's desktop or browser appearance in different ways [15]

The definitive statement on netArt was published in a self-conducted interview by Mark Amerika (with his ideal reader) as 'instantaneously distributed mindshare' ... 'a footprint in the electrosphere before the dot.coms came to the scene' (that) '... died before the dot.com market crash.'[16] This strategy underscores the immediacy of what Amerika calls netArt's 'surf-sample-manipulate' properties. In this manifestation, netArt is the life-practice of not only making history, but of making history up. Bypassing the institution, netArtists decided for themselves that they were artists and that their work was significant in the history of the internet. netArtists are still writing the history of netArt as if it has reached its end, whilst at the same time perpetuating the practice, in the act of writing its history.

\section{References.}

[1] Poster, M., The Mode of Information, Polity, Cambridge, 1990.

[2] Haraway, D.J., Modest_Witness@Second _Millenniu:FemaleMan ${ }^{\complement}{ }_{-}$Meets_OncoMouse ${ }^{\mathrm{TM}}$ Routledge, London and New York, 1997, p2.

[3] Benjamin, W., "The Work of Art in the Age of Mechanical Reproduction", 1936, (trans. H. Zohn) in Illuminations, Schocken, NY, 1968, pp 217-251.

[4] Weber, S., Mass Mediauras: form, technics, media, Power Press, Sydney, 1996.

[5] Virilio, P., Open Sky, Verso, London, 1997

[6] Poster, 1990, op. cit.

[7] Laurel, B., "Art and Activism in VR", Wide Angle

15:4, October 1993, p 17. 
[8] Nalder, G. (2001) Realising the Virtual: the internet as a space for transformatory art practice Doctoral Dissertation: URL: http://www.glendanalder.id.au [9] Poster, M. Postmodern Virtualities

URL: http://www.hnet.uic.edu/mposter/ writings/internet.html Accessed 6.4.1998.

[10] Kroker, A, Kroker, M, and Cook, D. (eds) Panic Encyclopedia: The Definitive Guide to the Postmodern Scene, URL:http://www.freedonia.com/panic/ Accessed 2.2.1997.

[11] Goodall, J., "General Adaptation Syndrome: Hypochondrias of the Fin de Siecle" in Grace, H. Aesthesia and the Economy of the Senses, Nepean, UWS, 1996, p 81.

[12] Starrs, J. and Cmielewski, Diagnostic Tools for the New Millennium URL: http://www.studioxx.org/maid encore/intros/starrs.html Accessed 7.3.1999.

[13] Maturana, H. The Biology of Self-Consciousness (unpublished manuscript) c1993.

[14] Ascott, R., "The Shamanic Web: art and mind in emergence" in Galloway, A., and M. Amerika, Digital Studies: being in cyberspace URL:

http://www.altx.com Accessed 15.3.1999.

[15] Lialinas, O., Art Teleportacia URL:

http://art.teleportacia.org/ Accessed 2.5.1998.

[16] Amerika, M., "Making History Up: A Serial

Question Mark", Amerika On-line \# 17, Telepolis:

URL:http://www.heise.de/tp/english/kolumnen/ame/447

5/1.html Accessed 19.12.2000. 